\title{
Raising inclusion through an online community
}

\author{
Susana Capitão \\ School of Health \\ Polytechnic Institute of Porto, \\ Portugal. \\ Rua Valente Perfeito, 322 \\ 4400-330 Vila Nova de Gaia, \\ Portugal. \\ +351222061000 \\ susanacapitao@gmail.com
}

\author{
Ana Margarida Almeida \\ Department of Communication \\ and Art/CIC.Digital/DIGIMEDIA, \\ University of Aveiro, Aveiro, Portugal. University of Aveiro, Aveiro, Portugal. \\ Campus Universitário de Santiago \\ 3810-193 Aveiro, Portugal. \\ +351234370 389 \\ marga@ua.pt
}

\begin{abstract}
The inclusion of children with deafness may be enhanced by the use of social web tools. In this scenario, building collaborative relationships among the school community as a whole is a very important process, being crucial to better understand the role of families in potentiating learning in the different contexts beyond school. This study aims to understand how the social web can facilitate the development of these communities by enhancing the learning of new skills by parents, students and professionals. Following a two cycle action research methodology, the authors developed and analyzed the evolutionary dynamics of an online community at a public school with students with deafness and identified drivers of change and improvement. Evidence was collected as to the added value of using the online community for the communication between parents and professionals and between parents and children, generating further support for the learning of children with deafness. The results have also indicated the need to promote greater training for professionals and families concerning the implementation of parental involvement dynamics between home and school.
\end{abstract}

\section{CCS Concepts}

-Social and professional topics $\rightarrow$ user characteristics $\rightarrow$ people with disabilities systems $\bullet$ Social and professional topics $\rightarrow$ Professional topics $\rightarrow$ Computing education $\rightarrow K$ 12 education $\cdot$ Human centered computing $\rightarrow$ accessibility -accessibility systems and tools.

\section{Keywords}

Parental engagement, family, education, deafness, community, social web.

Permission to make digital or hard copies of all or part of this work for personal or classroom use is granted without fee provided that copies are not made or distributed for profit or commercial advantage and that copies bear this notice and the full citation on the first page. Copyrights for components of this work owned by others than the author(s) must be honored. Abstracting with credit is permitted. To copy otherwise, or republish, to post on servers or to redistribute to lists, requires prior specific permission and/or a fee. Request permissions from Permissions@acm.org.

DSAI 2016, December 01 - 03, 2016, Vila Real, Portugal

Copyright is held by the owner/author(s). Publication rights licensed to ACM. ISBN 978-1-4503-4748-8/16/12 \$15.00

DOI: http://dx.doi.org/10.1145/3019943.3019963

\section{INTRODUCTION}

Over the years, there has been a growing focus on inclusion, namely in what that concept means in the school context. School inclusion refers to respecting individual differences, assuming diversity in terms of curricula and teaching/learning strategies, in a complex individual and institutional process [1]. The advantages of having a school that is prepared to promote the development of children with disabilities is not only for those students, but also for any other student, who can benefit from the professional expertise, and become better prepared to be an active citizen in an inclusive society.

Technological evolution and its influence in education is a growing reality. New opportunities are emerging for the

participation of students with special needs: there are new and easier tools to access information and communicate, being possible to use of a wide variety of technologies to support the learning processes of students with disabilities, namely with deafness. Back in 2003, the Becta Agency identified the major benefits of ICT for the students' inclusion, asserting its role in promoting greater autonomy, giving students the opportunity to showcase their potential and achievements, as well as the possibility of creating tasks suitable to their individual abilities [2].

The role of the family within the school, has also evolved over the last decades. Parental engagement is expected to reflect the active and personal role of the family in the child's learning, including the informal aspects that can be triggered by the home environment from parents with their children [3].

The family centred approaches have been recognized as the most effective and useful, particularly in the case of children with special needs. Parents are empowered to recognize the abilities and strengths of their child, and to have a more active role in the overall developmental process [4].

\section{FAMILIES, SCHOOLS AND DIGITAL MEDIA}

Digital technologies are an important part of our daily life, and, particularly for current students, they are an undeniable education resource, nowadays and in their future. The possibility of easily building learning networks enables an 
increased acknowledgement of the existing diversity and encourages social movements and valuable collaboration experiences, meeting the needs of the students in a networked society [5]. The education systems are now facing this new challenge and are pushing forward to become more customized, regarding the needs, interests and potential of each and every student [6].

New skills arise as essential for the students [7] that go beyond knowledge in its pure sense; one of these new skills is related to the learning and innovation dimension creativity, innovation, critical thinking, problem solving, communication and collaboration - where digital technologies may be a valuable asset.

Developing effective communication and collaboration between school professionals and the students' families, in order to promote parental engagement, has been identified as a key factor in improving students' school results $[3,4,8]$. Several organizations advocate that it is a fundamental right and duty for parents to be active participants in their children's education, since they are their life first and long lasting educators [9] (OECD, 2012). The communication quality between parents and children and parents and professionals seems to be essential to pursue a high quality education for young children [9-11].

The use of online websites, blogs and social networks to develop communities of practice amongst the school system members, can foster the communication between participants, by giving them access to updated information without schedule constraints or the need of face-to-face meetings. However, some state that most of these online communities have a unidirectional information delivery, from the school to the families, which limits not only the communication itself but also the collaboration skills potential development [12]. This concept has evolved from learning communities to learning networks [13 - 16], where the learning develops through a network of relationships that characterize the context and the nearness for inclusion and participation. Anyone can be a mentor as long as they master a particular topic or subject. Therefore, rather than having and relying solely on one teacher, the network fosters multiple points of view, encouraging the sharing of knowledge and questioning [14].

Within the context of deafness, these dimensions are particularly relevant. Parents of children with deafness are faced with several lifelong doubts and challenges. The team (teachers, sign language teachers, speech and language therapists, clinicians, etc) must acknowledge those needs in order to better support these families and children [17). Even though the available web resources offer a wide range of information about deafness and its particular issues, very few are available in Portuguese (written or signed) or are the focus of widespread published research, which can increase the risk of misinformation [18].

Several authors have identified the potential of the Internet, including web services, in promoting the functioning and inclusion of the person with hearing loss. Pedrosa [19] considers that the Internet is bringing new implications for these people, since communication is the area where they face major barriers. Now there are infinite communication possibilities because the Internet potentially promotes multiple learning by using image to convey many subjects. Furthermore, the web also encourages the development of communication and language by providing the use of reading and writing in meaningful and functional interactions. It also fosters the growth of interpersonal relationships, autonomy, initiative, and self-confidence. According to Barak and Sadvosky [20] the web brings extra benefits for people with hearing loss for two basic reasons: the communication mode, which is primarily based on visual channels (text and image), and the ability of not showing the disability to other users, therefore, feeling safer and with greater equality in the interaction. Online, people with deafness can communicate in the same way as other users: reading and writing, freely exchanging messages via e-mail, forums, chats and blogs without having to reveal their deafness condition [21]. In what concerns education, the use of resources in digital format facilitates content review, the focus on specific points, as well as an easier customization of the materials to students' individual needs. Students with deafness often need to review content and study outside the classroom, taking it home, thus working at their own pace and developing a greater independence in the learning process, which also becomes more practical with content in electronic format [22]. Furthermore, it must be noted that the usual text books, conceived for the regular student, aren't suitable for children with deafness. In this case, there is a constant need for the team of experts to adapt or create new resources. Especially when sign language must be used to convey information, the pictures of the signs are frequently used with the printed forms our printed posters in classes. The digital media is now opening the possibility for a major upgrade in the use of sign language in the video modality in resources that support the teaching/learning of this specific population, in a way that couldn't be done before, as it is now simple, easy to use and user friendly.

\section{METHOD}

The study presented in this paper aimed at understanding how digital media, by means of a online community, can contribute to support networks between the families and the school team of children with deafness. The main interest is to understand and find answers that make it possible to take action in this particular situation, which is consistent with a critical paradigm [23]. Furthermore, the study has naturalistic features because it focuses on a social reality, that results of subjective points of view from both the individuals and the community involved. An action-research methodology provides the interconnection of the theoretical and practical knowledge because "theory is lived in practice and practice becomes a form of living theory" [24]. An action-research methodology focuses on the process, acknowledging the constant changes and renovations, which 
are influenced by the context in general and the human interactions that will be studied.

\subsection{Context and Participants}

This study was developed in a public school with students with deafness. In this school, students can be enrolled in regular classes and in bilingual classes. The participants of the study were the professionals and the families of children from pre-school (3-6 years old) to the $4^{\text {th }}$ grade (10 years old). In tables 1 and 2 the study's participants are detailed.

Table 1. Families' distribution of the type of class and grade level of the corresponding children with deafness, in each research cycle.

\begin{tabular}{cccc}
\hline $\begin{array}{c}\text { Grade } \\
\text { level }\end{array}$ & Class Type & $\begin{array}{c}\text { 1st } \\
\text { Research } \\
\text { Cycle }\end{array}$ & $\begin{array}{c}\text { 2nd } \\
\text { Research } \\
\text { Cycle }\end{array}$ \\
\hline \multirow{2}{*}{ Pre-school } & Regular & 0 & 0 \\
& Bilingual & 4 & 2 \\
\hline $\begin{array}{c}\text { 1st to 4th } \\
\text { Grade }\end{array}$ & Regular & 10 & 4 \\
\hline \multicolumn{2}{c}{ Total } & 4 & 3 \\
\hline
\end{tabular}

Table 2. Professionals' distribution of the type of class and grade level of the corresponding children with deafness, in each research cycle.

\begin{tabular}{|c|c|c|c|}
\hline Professional & Class Type & $\begin{array}{c}1 \text { 1st } \\
\text { Research } \\
\text { Cycle } \\
\end{array}$ & $\begin{array}{c}\text { 2nd } \\
\text { Research } \\
\text { Cycle } \\
\end{array}$ \\
\hline \multirow{2}{*}{$\begin{array}{l}\text { Kindergarten } \\
\text { teacher }\end{array}$} & Regular & 0 & 0 \\
\hline & Bilingual & 0 & 1 \\
\hline $\begin{array}{l}\text { Regular } \\
\text { teacher }\end{array}$ & Regular & 3 & 2 \\
\hline \multirow{2}{*}{$\begin{array}{c}\text { Special } \\
\text { Education } \\
\text { teacher }\end{array}$} & Regular & 2 & 1 \\
\hline & Bilingual & 5 & 4 \\
\hline $\begin{array}{c}\text { Sign } \\
\text { Language } \\
\text { teacher }\end{array}$ & Bilingual & 4 & 4 \\
\hline \multirow{2}{*}{$\begin{array}{l}\text { Speech and } \\
\text { Language } \\
\text { Pathologist }\end{array}$} & Regular & 1 & 1 \\
\hline & Bilingual & 4 & 5 \\
\hline \multicolumn{2}{|c|}{ Total } & 19 & 18 \\
\hline
\end{tabular}

\subsection{The online community}

The online community named Vozes de Mãos Dadas (Voices giving hands www.vozesmaosdadas.org) was the main source of data. In order to better protect the identity of the participants, the community had a public area and a private area, directed to registered users: the participants of the study. All the registered members were allowed to not only comment, but also to publish in all areas of the online community. At registration, the new members filled an identification form and agreed with the terms of service. The public area consisted of four areas: home, presentation, news, to know more. In the private area, there were subareas for each class, for the families, for document upload/download, a calendar and a forum. The publishing could be made by different means of communication (text, picture, video), with the possibility to embed the videos or the interactive games built online in other platforms.

\subsection{Research design}

The development of interactions amongst an educational community was analysed, namely the several elements of the team and the families of the children with deafness from that school. Using an action-research methodology, the evolutionary features of the parental engagement processes were documented. It's clear that both chaos and order can emerge from this dynamic, with retreats as advances along the research cycles [24]. That being said, this study involved two research cycles. In the beginning of the first research cycle questionnaires were applied in order to describe, amongst others, the digital literacy and habits of the participants [25]. Then, the online community Vozes de Mãos Dadas was created.

To ensure that the digital literacy of the participants had a minor impact in the online community participation, a training program was developed directed both at the professionals and the families, each in a different schedule, which started in the first research cycle. During training, participants had to perform tasks in the online community, using social web tools and services. Face-to-face and online support was given to the participants, since one of the stages of the research takes part of the school team. In the end of the $1^{\text {st }}$ research cycle, the data concerning the online episodes was gathered. To better identify changing proposals to implement in the $2^{\text {nd }}$ research cycle, the participants' opinion was obtained by four focus group interviews: teachers, sign language teachers, speech and language therapists, and families.

The data was gathered from the focus group interviews that took place between the first and the second research cycle and also from the digital information records of the interactions and publications of the participants on the online community during the first and the second research cycle.

Then, the content analysis of the data took place, using the qualitative analysis software WebQDA. The content analysis categories were initially built considering the literature described in the previous sections and also the studies of Beja [26], Lopes [27], Miranda [28] and Pais et al. [29]. Even so, throughout the reading of the data, new categories emerged, in a very dynamic process, 
characterized as being a nomothetic and ideographic approach.

The following four categories, which were later divided into sub-categories, were created: 1) Episodes based on practice (episodes registered in the online community, by means of publications or comments); 2) Practice constraints (situations, characteristics, embarrassments that were reported in the focus group interviews); 3) Factors that promoted the interactions; 4) Communication-interaction strategies.

To describe the data, a series of features concerning the school grade, type of class, type of professional, type of family bond, year, month and place published were used.

The data was organized in frequency tables considering the sentence as the minimal analysis unit. A triangulation technique was also applied to relate the different features and sources of the data.

\section{RESULTS}

\subsection{Episodes from the practices}

A total of 760 episodes were registered in the online community. These were then organized in 8 subcategories that enabled their analysis aiming at identifying which ones incremented professional and personal knowledge, as a mean for working with the children, making it possible to: share school and/or family events; or foster the communication between school and family (between the school professionals, between the families and between the adults and the children).

Graph 1 details the results concerning the adults' role amongst the participants.

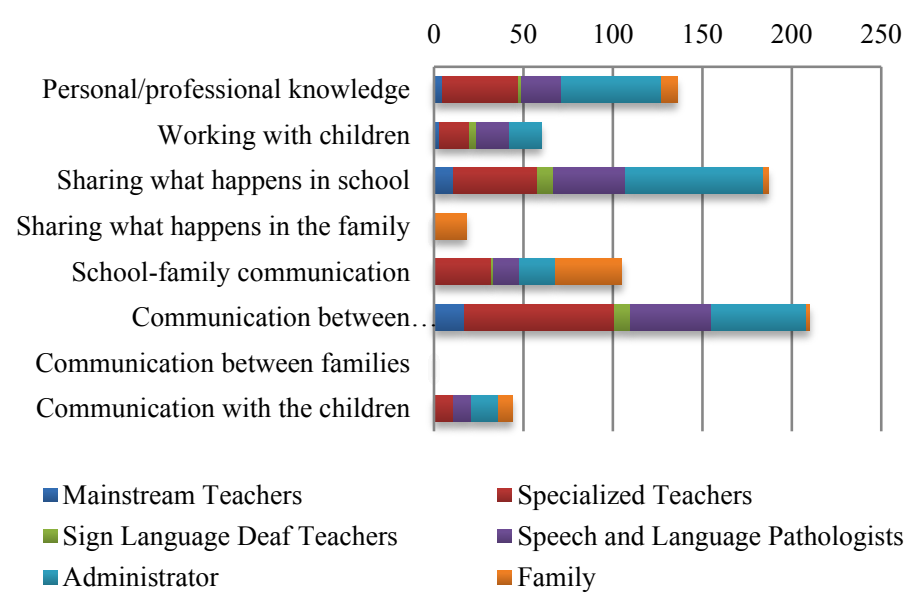

Graph 1: Online community episode's distribution considering the adults' role $(\mathrm{n}=760)$.

It was also possible to verify that most of the interactions within the online community were towards communication between professionals (208 in 760) and that there are plenty of sharing about what happens at school (187 in 760), followed by interactions for professional or personal knowledge (136 in 760). Among families, contrary to what happened with the professionals, there were very few interactions ( 2 in 760). However, interactions were also observed for the communication between schools and families (105 in 760). There was also evidence of the use of the community to support the communication with children (60 in 760).

The episodes by type of class were also analysed, in order to identify existing differences between regular and bilingual classes (Graph 2). Given the high number of episodes related to the Administrator, to better analyse these data without its influence, those were not considered in the forthcoming analysis.

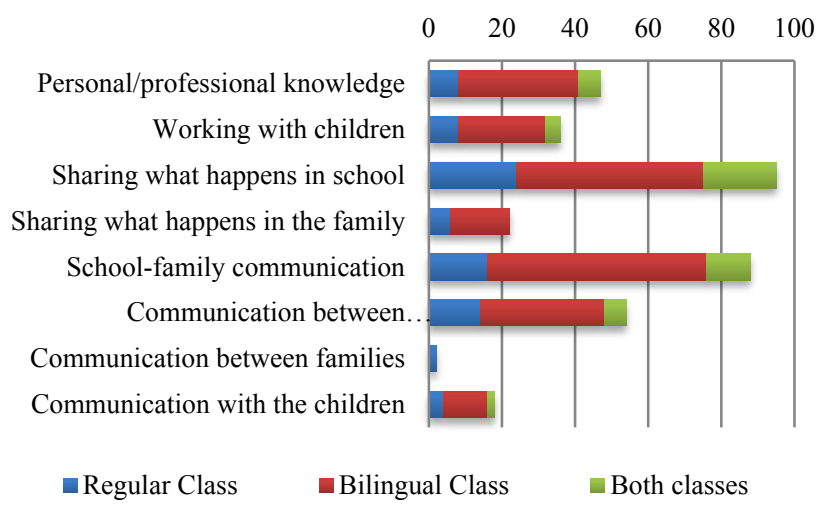

Graph 2: Online community episode's distribution $(n=347)$ considering the type of class, without the episodes associated to the administrator.

The results show that all kinds of episodes occur independently from the type of class, except in the case of communication between families that only occurred in when there were regular classes participants (2 in 347).

Different media (text, pictures and video) were used by the participants to share events that happened at school, describing the activities taking place throughout the school time, informing about the use of toys and commercial products that address deafness features, publishing activities done at school by the children, and even describing the curricular projects that were being implemented. There was evidence of communication with the families when they posted comments to those publications. During the focus group interviews parents reported that the access to the online community allowed them to have more meaningful conversations with their children about the school day, enabling a more specific and daily support to their learning process. Also, the professionals reported to have received this feedback from the parents, in face-to-face conversations, where parents described how they used the materials and resources shared in the online community. As can be observed in the previous graph, the contributions also came from the families, in the form of comments and of publications regarding events and situations that occurred at home.

Participants also reported that the use of this online community gave them access to specific information about deafness, namely about "Hearing and deafness", "Hearing 
aid troubleshooting", "Language and Communication development", "How to have a conversation with a child with deafness", and "Current resources and services".

\subsection{Online participation: strengths and constraints}

During the focus group interviews, the participants described several constraints $(60$, in total) that influenced their online participation, as can be observed in the following graph.

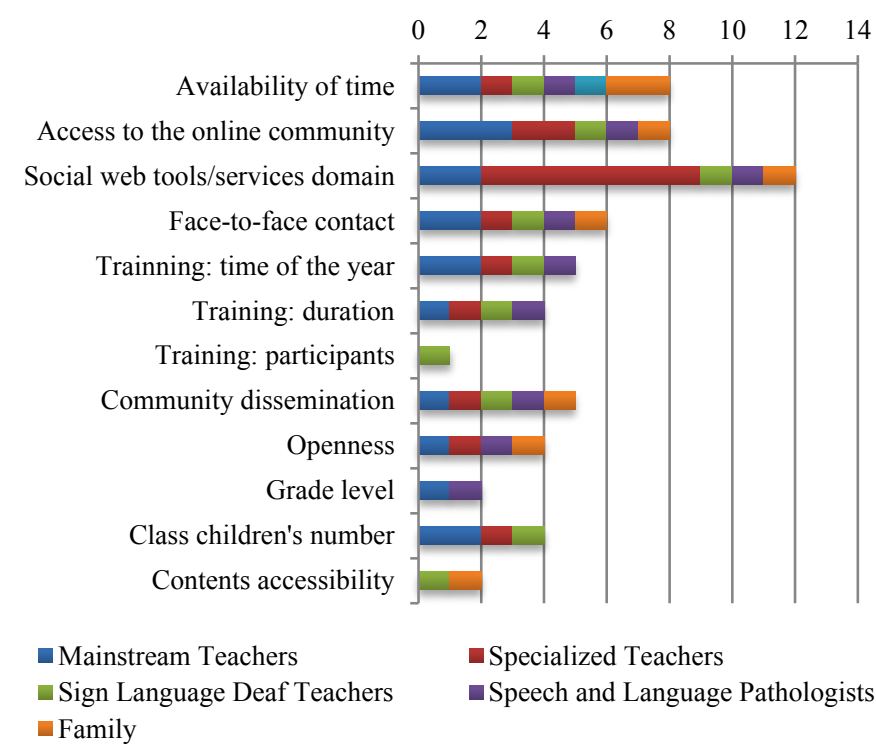

Graph 3: Participants opinion about the online community participation constraints' $(\mathrm{n}=60)$.

The lack of domain of the use of social web services and tools was one of the most cited constraints (12/60), followed by access limitations to the online community $(8 / 60)$ and the availability of time (7/60). On the other hand, the face-toface contact between the participants was considered a feature that facilitated online participation (6/60). Concerning the training, there were statements concerning the time of the year $(5 / 60)$, the duration $(4 / 60)$ and the type of participants $(1 / 60)$, that were considered to be influential factors. On the other hand, the participants indicated that the openness of the online community, that had private and public areas, might also have influenced the participation $(4 / 60)$. There were two groups of participants, namely the sign language teachers and the parents that highlighted the accessibility of the contents as an influencing factor $(2 / 60)$.

\section{CONCLUSIONS}

Our results have showed that the online community described in this article fostered the interaction between professionals and between parents and professionals. Thus, the existing teamwork networks at the school were enhanced. In addition, parental engagement was increased by means of an increased communication with professionals who accompany their children. One of the outstanding results in this context relates to the increased communication between schools and families in bilingual education classes, which points out to a very interesting trend when considering digital media's potential to improve inclusion settings, by allowing people with and without disabilities to enrich their interactions. Most interactions with the families were registered in episodes of sharing events that took place at school; but it was also noted that there were many interactions between parents and professionals through publications about family experiences, the work with children (for example, the use of the online community for them to write on the computer, to do a report about a class trip, to leave a message or a comment, to play and build interactive games,...), and also publications on more general topics, aimed at increasing professional or personal knowledge. In the focus group interviews, parents stated that participation in this online community helped them to better communicate with their children, giving visibility to what they were doing at school in a more visual mean of communication. This strategy was also reported by parents as fundamental to improve the lack of vocabulary of these children and to give them new means to take ownership of conversation topics and issues of interest on a daily basis one of the behaviours of parental participation described as having a major impact by authors such as Hart and Risley [30], Lucas [31] and Blanford and Knowles [32]).

Furthermore, the results signal the need to clarify the role of families in their children's learning, amongst both the parents and the professionals. The basic training of the education teams regarding the skills demanded to effectively boost parental engagement still needs to be improved [33]. Families are not used to taking initiative in their children's learning, expecting that the school asks them for information directly.

With this study, we also verified an increment of the communication between professionals, mainly by sharing school activities and sharing specific information towards professional and individual knowledge. In the professionals' opinion, taking part in the community has led them to easier access to information about what happens in school and a greater exchange of ideas between professionals working with different groups, making it possible to know the type of work that is developed and also the features and materials used. Furthermore, it was possible to enlarge professional development by publishing information on various topics. It was noted, however, that the exchange of ideas among the participants (through comments and publications) mostly regarded sharing school activities, rather than more general information, making it a less personalized experience for a student, a family or a class.

These interaction dynamics were influenced by several factors that affected the participation in the community. The lack of knowledge on new technologies, tools and social web services was one of the most mentioned by participants in the interviews. Despite developing two editions of a training workshop for professionals, as well as individual or group training sessions with families, this constraint was one 
of the most mentioned factors, having also been indicated the need for more training in the use of social web tools. The professionals recognized the strengthening of networks as an advantage, especially in the case of parents who are geographically distant from school. By using the online community, those families have an easier access to information and become aware of the topics and issues that are being dealt with in the classroom.

Both professionals and family members considered that the fact that parents of other students without deafness had access to the online community was an added value. They reported that the resources available could be useful for everyone and, on the other hand, it would foster a greater knowledge about the education of children with hearing loss and of what "being deaf" means, therefore promoting a greater inclusion, empathy and sense of belonging to the extended educational community. We believe that the need for building relationships between participants by elapsed interactions based on a common motivation will lead to the development of a sense of belonging and mutual commitment and to raise inclusion in the school-family scenario.

\section{ACKNOWLEDGMENTS}

Our thanks to all the families, teachers and speech and language pathologists, that participated in this study.

\section{REFERENCES}

[1] Brocardo, J. 2009. Desenvolvimento da Educação Inclusiva: Da retórica à prática. Resultados do Plano de Acção 2005-2009. Lisboa: Editora Cercica.

[2] Becta Agency. 2003. What the Research says about ICT supporting special educational needs (SEN) and inclusion. ICT Research. Available in www.becta.org.uk/research/ictrn.

[3] Harris, A., \& Goodall, J. 2007. Engaging Parents in Raising Achievement: Do Parents Know They Matter? Warwick: University of Warwick.

[4] Gregg, K., Rugg, M., \& Souto-Manning, M. 2011. Fostering Family-Centered Practices Through a FamilyCreated Portfolio. The School Community Journal, 21 (1), 53-70.

[5] Rudd, T., Gyfford, C., Morrison, J., \& Facer, K. 2006. What if...Re-Imagining Learning Spaces. Bristol: Futurelab.

[6] Redecker, C. (2009). Review of Learning 2.0 Practices: Study on the Impact of Web 2.0 Innovations on Education and Training in Europe. Joint Research Centre, Institute for Prospective Technological Studies. Luxembourg: European Commission.

[7] The Partnership for 21st Century Skills. 2009. P21 Framework Definitions. Available at http://www.p21.org/index.phpoptio=com_content\&task $=$ view\&id=504\&Itemid=18 5

[8] Henderson, A. 2013. High Impact Family Engagement: A Core Strategy for School Improvement. In $G$.
Education (Ed.), A Powerful Impact: The Importance of Engaging Parents, Families and Communities in improving Students Success: Copytech.

[9] OECD. 2012. Research brief: Parental and Community Engagement Matters, Encouraging Quality in Early Childhood Education and Care (ECEC).

[10] MacNaughton, G., \& Hughes, P. 2008. Parents, partnerships and power. In F. d. Graaff \& A. v. Keulen (Eds.), Making the Road as We Go, Parents and Professionals as Partners Managing Diversity in Early Childhood Education: Den Haag, Bernard van Leer Foundation.

[11] Urban, M. 2009. Early Childhood Education in Europe: Achievements, challenges and possibilities. Education International.

[12] Grant, L. 2009. Learning in Families: A review of research evidence and the current landscape of Learning in Families with digital technologies. Bristol: Futurelab.

[13] Ala-Mutka, K. 2010. Learning in Informal Online Networks and Communities. European Commission, Institute for Prospective Technological Studies (EUR $24149 \mathrm{EN})$.

[14] Denning, P. 2014. The Profession of IT Learning for the New Digital Age. Communications of the ACM, 57 (9), 29-31.

[15] Dias, P. 2013. Inovação pedagógica para a sustentabilidade da educação aberta e em rede. Educação, Formação \& Tecnologias (july - december, 2013), 6 (2),4-14.

[16] Sloep, P. \& Berlanga, A. 2011. Redes de aprendizage, aprendizage en red. Comunicar, 37, v. XIX, 2011, Scientific Journal of Media Literacy, 55-63.

[17] Dalzell, J., Nelson, H., Haigh, C., Williams, A., \& Monti, P. 2007. Involving families who have deaf children using a Family Needs Survey: a multi agency perspective. Child: care, health and development, 33(5), 576-585.

[18] Zaidman-Zait, A., \& Jamieson, J. R. 2004. Searching for cochlear implant information on the internet maze: Implications for parents and professionals. Journal of Deaf Studies and Deaf Education, 9 (4), 413-421.

[19] Pedrosa, N. (Cartographer). 2002. A Internet e a Deficiência Auditiva. Available at www.intervir.net

[20] Barak, A., \& Sadovsky, Y. 2008. Internet use and personal empowerment of hearing- impaired adolescents. Computers in Human Behavior, 24 (5), 1802-1815.

[21] Power, D., \& Power, M. R. 2009. Communication and culture: signing deaf people online in Europe. Technology and Disability, 21(4), 127-134.

[22] Becta. 2005. Using ICT to support the inclusion of deafpupils in mainstream schools. Include ICT. Disponível em 
http://foi.becta.org.uk/content_files/corporate/resources /foi/archived_publications/in clude_ict_see_hear.pdf

[23] Blaxter, L., Hughes, C., \& Tight, M. 2006. How to research: Open Univ Pr.

[24] McNiff, J., \& Whitehead, J. 2002. Action research: Principles and practice (2 ed.). London: Routledge.

[25] Capitão, S., Almeida, A. M., Vieira, R. 2012. Connecting Families and Schools of Students with Deafness: Describing the ICT and Internet use in Education. In Proceedings of the 4th International Conference on Software Development for Enhancing Accessibility and Fighting Info-exclusion (DSAI 2012). Procedia Computer Science, Volume 14, 2012, Pages 163-172.

[26] Beja, M. 2009. Escola e família: da inevitabilidade da comunicação à construção de uma realidade relacional (estudo exploratório no 1 o ciclo do Ensino Básico). $\mathrm{PhD}$, Universidade da Madeira, Funchal, Madeira. (02/D/200)

[27] Lopes, S. 2012. Web 2.0, PC e EFA: impactes de uma oficina de formação de professores. PhD Degree, Universidade de Aveiro, Aveiro.

[28] Miranda, M. 2009. Processos de Colaboração e Liderança em Comunidades de Prática Online - O caso da@rcaComum,uma Comunidade Ibero-Americana de
Profissionais de Educação de Infância. Tese de Doutoramento, Universidade do Minho, Braga.

[29] Pais, F., Vasconcelos, S., \& Capitão, S. 2012. Blogues educativos: análise de conteúdo e factores de longevidade. Internet Latent Corpus Journal, 2(2), 3755.

[30] Hart, R., Bober, M., \& Pine, K. 2008. Learning in the Family: Parental Engagement in Children's Learning with Technology: Intuitive Media Research Services/University of Hertfordshire.

[31] Lucas, B. 2013. Engaging Parents in Schools. In G. Education (Ed.), A Powerful Impact: The Importance of Engaging Parents, Families and Communities in improving Students Success: Copytech. Available at www.copytech.com.

[32] Blandford, S., \& Knowles, C. 2013. Parent and Family Engagement and its Impact on Students with High Needs in England. In G. Education (Ed.), A Powerful Impact: The Importance of Engaging Parents, Families and Communities in improving Students Success: Copytech. Disponível em www.copytech.com.

[33] Goodall, J., \& Vorhaus, J. 2011. Review of best practice in parental engagement. Research Report DFERR156. Uk Government, Department of Education. 